\title{
Economics of Coastal Erosion and Adaptation to Sea Level Rise
}

Sathya Gopalakrishnan - The Ohio State University

Craig E. Landry - University of Georgia

Martin D. Smith - Duke University

John C. Whitehead - Appalachian State University

\begin{abstract}
This paper provides a review and synthesis of geo-economic models that are used to analyze coastal erosion management and shoreline change. We outline a generic framework for analyzing risk-mitigating and/or recreation-enhancing policy interventions within a dynamic framework, and we review literature that informs the nature and extent of net benefit flows associated with coastal management. Using stated preference analysis, we present new estimates on household preferences for shoreline erosion management, including costs associated with ecological impacts of management. Lastly, we offer some guidance on directions for future research.
\end{abstract}




\section{Economics of Coastal Erosion and Adaptation to Sea Level Rise}

The economic value of physical capital stocks located in areas vulnerable to coastal erosion and storms has been estimated at around $\$ 1.2$ trillion (US) (Nordhaus 2006). Historically, transportation, shipping, natural resource extraction, and military defense drove development of the coastal zone, but during the $20^{\text {th }}$ century much of the impetus for coatal development shifted to residential housing, supporting commercial businesses, and associated publilc infrastructure investments. Major contributors to this shift include rising household incomes, a demographic transition of large segments of the population into retirement, and increasing demand for recreation and leisure services provided by the unique coastal environment.

Economic, legal, and social institutions influence coastal development patterns, with multiple levels of government playing a role. Improvements to private property complement coastal recreation and leisure activites along the shoreline, and investments in public infrastructure faciliate access to coastal amenities. Common law precedents and statutory law provisions (including building standards and zoning) define the development possibilities of coastal private property; submerged lands are managed by the federal government under the public trust doctrine, and infrastructure design and investment decisions are guided by local and state governments. These domains of human agency interact within the political sphere, often giving rise to legal conflict, compromised action, and second-best outcomes (Green \& PenningRowsell 1999; Bennear \& Stavins 2007).

Given the complex, multi-facted interface of terrestial, marine, and atmospheric systems, the coastal environment is highly dynamic. Hydrologic and sediment inputs from the land interact with coastal ocean systems, giving rise to saltmarshes, brackish estuaries, persistent and ephemeral inlets, and barrier islands with sandy dunes and beaches. Coastal barrier islands and estuarine shorelines are both subject to gradual and punctuated evolutionary changes. Stochastic storm arrivals are pulse (episodic) disturbances along the coast, whereas relentless waves and sea level rise are press (chronic) disturbances (McNamara et al. 2015). Erosion and accretion of sediments affect shorelines along oceans and estuaries. For sandy shorelines like much of the U.S. East and Gulf coasts, sea level rise and storms can cause marsh and barrier island migration, with overwash and inlet formation playing a central role in barrier island adaptation. The interaction of complex coastal ecosystems with socio-economic and political apparati give rise to a fully coupled human-natural system (Smith et al. 2015).

In this paper, we review and synthesize the literature on geo-economic models of beach erosion management. We discuss the literature on economic benefits associated with coastal sediments and short- and long-term costs stemming from erosion management. Our discussion of costs includes not only pecuniary and capital costs, but also ecological impacts and effects on provision of ecosystem services. We analyze primary data on individual preferences for coastal 
erosion management and explore implications for adaptation to sea level rise and environmental change. We conclude with recommendations for directions of future research.

\section{Geo-economic Models of Beach Erosion Management}

Geophysical processes that affect the state of coastal resources include alongshore sediment transport, terrestrial-marine sediment flux and deposition, wave climate and run-up, stochastic storm arrivals, sediment overwash and deposition in back-barrier lagoons, and sea-level rise. Following a rich tradition in bioeconomics (Gordon 1954; Scott 1955; Smith 1969; Clark \& Munro 1975; Hartman 1976; Samuelson 1976), geo-economic models treat coastal resources as natural capital that generates a stream of service flows over time. A state equation (or system of state equations) characterizes the changes in natural captital stocks over time (and possibly space), and links these changes to human decisions. As such, geo-economic models couple geomorphological processes with economic decision-making, welfare, and institutions in order to evaluate the efficiency and sustainability of resource allocation mechanisms. They also describe the behavior of communities managing coastal resources. In this sense, geo-economic models parallel developments in bioeconomics by having both positive and normative content.

Early work in developing capital-theoretic models to explore the interactions of complex physical processes and economic decisions focused on management decisions in a single location along the shoreline (Smith et al. 2009; Landry 2011). The general model for optimal beach management in a single location can be written as:

$$
\max _{a(t)} \int_{0}^{T} e^{-\delta t}(N B(q(t), a(t))) d t
$$

subject to:

$$
\frac{\partial q(t)}{\partial t}=G(q(t), a(t) ; \theta)
$$

In model (1-2), $q$ is a state variable that represents the stock of beach capital in the community at time t. $a(t)$ is a vector of controls representing human behavior - decisions to construct structures such a sea walls or add sand to increase beach width through nourishment, $t \in[0, T]$ indexes time, $\delta$ is the discount rate. The net benefits function, $N B$, measures the instantaneous flow of services provided by beach capital $(q)$ and coastal adaptation decisions $(a) . T$ represents the planning horizon, which may be framed as finite or an infinite horizon problem (i.e., $T \rightarrow \infty$ ). The function $G$ in Equation (2) represents the coastal dynamics that determine the geophysical constraints faced by a social planner who makes investments in beach capital or shoreline protection. The state transition function $G(q, a ; \theta)$ depends on the previous stock of beach capital (e.g. beach width), the chosen action (a), and a vector of parameters describing 
geomorphological processes $\theta$. A coastal manager's problem is then to choose actions across time to maximize a stream of discounted net benefits.

Like Hotelling theory in non-renewable resource economics and Faustmann theory in renewable resource economics, the model in (1) and (2) can be both positive and normative because it simulataneously describes what individual communities may do and prescribes what they should do. In contrast, behaviors in the archetypal positive and normative models in renewable resource economics of the fishery are radically different; the descriptive model of how the fishing industry behaves under open access or regulated open access is nothing like the prescriptive model optimal management (Gordon 1954; Smith 1969; Homans and Wilen 1997; Clark and Munro 1975). The starting place for erosion management is an individual community stabilizing its shoreline by deciding whether, when, and how much to engage in beach nourishment. Beach nourishment is the process of rebuilding an eroded beach by dredging sand from another location and spreading it on the eroded beach and dune system (Dean 2002). Beach managers choose the frequency (how often to nourish the beach) and extent (how far out to build the beach) of nourishment with the objective of maximizing a stream of net benefits subject to the geo-physical system and institutional constraints. Federal provisions of beach management-primarily under the domain of public water projects administerd by the US Army Corps of Engineers (USACE) - allow for public input into the decision-making process (USACE 2000). As such, beach managers' decisions can be limited or influenced by local opposition to beach nourishment projects or local support for otherwise sub-optimal plans. In some cases, the "locally preferred plan" can attain priority over the plan supported by project managers; this can entail alteration in beach width or changes in the nourishment schedule that conflict with geo-economic normative recommendations.

Nourishment is done periodically rather than continuously because it is characterized by large fixed costs-identifying sand borrow sites, mobilizing dredges, designing the project, and obtaining necessary permits. The periodic nature of nourishment makes it analogous to the Faustmann problem in forest economics (Smith et al. 2009, 2015). Nourishment can be represented as a periodic capital investment, which provides benefits (amenity flows and storm protection) that are capitalized by coastal property values and other economic activity. A beach manager then chooses the optimal interval between nourishment events. A critical distinction for beach nourishment is the public good nature of the output; since beach service flows are collectively consumed, there can be considerable heterogeneity in value and support for management initiatives. In principle, other management actions, such as installation of shoreline armoring or relocation of threatened structures, could be modeled in a similar framework, though we are unaware of any active research in these areas. 
Investments in shoreline defense involve feedbacks that affect the rate of change in shoreline conditions. Here, too, there are important parallels to bioeconomics in which the rate of change in the natural capital stock (e.g. the growth of fish) is affected by human decisions (e.g. the harvest rate). In geo-economic models, beach nourishment decisions influence the shoreline erosion rate; a nourishment project creates a "bump" in the shoreline, and the discrete addition of sand to widen a beach forms a wedge on the shoreface (Fig. 1). As a result, there is a tendency for the newly placed sand to diffuse in the alongshore and cross-shore dimensions and to smooth out along the shoreface as the shoreline returns to an equilibrium shoreface state (Dean 2002). This leads to an acceleration of erosion in the nourished area in the immediate aftermath of nourishment project and a corresponding decrease in erosion in adjacent areas to which sediments flow. The more frequently a community nourishes, the greater the average erosion rate and thus the more sand that is required to maintain the beach. That is, the choice of nourishment interval drives the input demand for sand. A key result is that the optimal nourishment interval can increase or decrease in response to higher variable costs of sand, depending on this accelerated erosion of a nourished beach. This seemingly counterintuitive result - that the demand for nourishment sand demand can slope downward or upward - highlights important tradeoffs between intensive (how often to nourish) and extensive margins (how far out to build a beach) in the beach management problem (Smith et al. 2009).

The alignment of positive and normative perspectives in a single-community geo-economic model rests on several strong assumptions. First, communities are assumed to be forwardlooking, monolithic in their support for active management, and informed about future expected erosion. Weighing in favor of this assumption is that the single-community model empirically predicts nourishment intervals for coastal North Carolina (Gopalakrishnan et al. 2011). A recent extension of the model to account for stochastic storm arrivals improves the fit with historical data (McNamara et al. 2015). The extent to which the model performs similarly in other regions is unknown. Weighing against this assumption is broad disagreement in public opinion about climate change and political controversies that have been witnessed surrounding beach nourishent and sea-level rise adaptation plans. If individual communities have heterogeneous beliefs about the science that predicts likely future sea level rise and storm scenarios, then the model lacks important positive content. Indeed, a model with hypothetical climate beliefs that vary across communities predicts striking differences in investments in shoreline defenses (McNamara \& Keeler 2013).

Second, local decisions are assumed to capture a comprehensive set of public goods. The focus in modeling coastal management is on storm protection and recreational benefits of wide beaches and robust sand dunes. These public goods are exactly what we would expect coastal managers to consider in decision-making with the caveat that local communities do not capture 
all of the recreational benefits that flow to day-trippers and overnight visitors who live elsewhere. Coastal engineering, however, can impose externalities affecting other ecosystem services that may not be considered. Dredging nourishment sand, for instance, disturbs the benthos and could have consequences for fisheries. Moreover, there are concerns that beach nourishment can threaten charismatic wildlife like sea turtles. In essence, alignment of positive and normative modeling requires that the net benefits function in (1) includes all of these public goods. However, the empirical work that demonstrates the single-community model's ability to predict nourishment intervals does not account for these other ecosystem services (Gopalakrishnan et al. 2011; McNamara et al. 2015). We examine some of the tradeoffs across stabilizing shorelines and changes in other ecosystem values in a stated preference study discussed below.

Third, there must be a close correspondence between the optimization problem as forumalted by equations (1-2) and the policy model utilized by planners and decision makers. The majority of ongoing beach nourishment projects fall under federal jurisdiction (USACE, with permitting and compliance issues resting with other agencies); federal procedures for project justification rely on demonstration of value due to protection of the built environment (buildings and infrastructure) in simulated storms (USACE 2000). Guidelines specify use of 'actual market values' as estimates of property value, though in practice value of comparable properties or replacement-cost-minus-depreciation are often used (Yohe 1993; Landry 2011). Only a limited proportion of benefits is permitted for recreation purposes (USACE 2000).

Fourth, there are no spatial spillovers from an individual community's decision-making. In reality, coastal management decisions in one location can create spatial externalities that affect geophysical conditions and the flow of economic benefits in other locations along the coast. This means that the single-community model may still be descriptive but would overlook the normative consequences of spatial spillovers. Over scales up to kilometers, such effects are well studied, and there are examples of stabilization and maintenance projects, like dredging, construction of jetties, or infrastructure projects, that have triggered striking coastline offsets in adjacent areas in a matter of years or decades. There is also increasing evidence that stabilization of an eroding shoreline-either through beach nourishment or hard structurescan affect long-term rates of shoreline change over surprisingly long distances up to tens of kilometers (e.g. Slott et al. 2010; Ells \& Murray 2012). Whereas coastal geomorphologists have long understood that human interventions to stabilize beaches can have spatial spillovers at local and regional scales, the economic implications of these spatial spillovers are not yet well understood. Recent work examining spatial-dynamic feedbacks with strategic interaction between two neighboring beach towns that make beach nourishment decisions suggests that, when towns implement localized stabilization policies (not accounting for the physical and economic implications of these dynamic spatial interactions) it results in suboptimal outcomes 
relative to coordinated management of the coastline (Gopalakrishnan et al. 2016). Specifically, strategic interactions lead communities to underprovide nourishment, and the problem worsens with greater climate forcing. A spatially heterogeneous policy that subsidizes the provision of beach nourishment, an impure public good with spatial spillovers, can potentially achieve a first-best coordinated solution. The implication is that spatial externalities contribute essential normative content that is ignored in the single-community model.

Despite some positive limitations of the single-community model-i.e. the potential for withincommunity economic heterogeneity, political processes, and variation in beliefs about climate science to influence decision-making - embedding the stylized single-community decision rule into a spatially extended geo-physical model yields striking results. When human and natural systems are coupled, significant and diverse feedbacks are possible, which can generate emergent dynamics that are not directly related to either the human or the natural systems. Using a simple spatially extended physical model (many communities arrayed along a straight coastline with an exogenous erosion component and spatial diffusion of sand), the singlecommunity decision rule can destabilze the whole coast and cause the time series of coastline changes to become chaotic (Lazurus et al. 2011). In this model, communities begin along a flat coastline kept in steady state with nourishment intervals that are synchronous. A tiny shock in one location along the coast propogates locally over space through diffussion. Individual communities, however, make nourishment decisions based only on their own experiences of erosion without regard to spatial externalities. Alongshore diffusion causes nourishment to become asynchronous, which amplifies and further propagates the shock over space until it has extended throughout the domain. Though highly stylized, this result points to the recklessness of spatially decentralized coastal planning as an adaptation strategy for climate change. Placing the single-community decision rule into a more complex (and more realistic) coastline model leads to an alternating pattern of suckers and free riders, where the sucker communities overprovide public goods relative to the free riders (Williams et al. 2013). In essence, these models base the decision rule on equation (1) but take account for more realistic spatialdynamics of coastal geomorphology. Neither of the resulting patterns appear in the normative literature on spatial-dynamic optimization of renewable resource systems (Brock \& Xepapadeas 2008,2010 ), suggesting that these spatially myopic behaviors are suboptimal. This raises an important question for coastal research: if we know that human interventions influence the dynamic physical system, can we begin to think of optimally managing entire coastlines for a state, region, or country?

The two-community model in Gopalakrishnan et al. (2016) provides a starting place for this normative discussion. With beach nourishment as an active management policy, dynamics of beach evolution at multiple locations along a continuous coastline can be modeled as a spatially diffusive process with nourishment sand moving from regions of high sand concentration to low 
concentration (smoothing bumps). Generalizing to continuous space along an entire coastline means that the planner chooses both time of nourishment and quantity of nourishment in each location. Nourishment decisions at any given location can affect future beach widths at all other locations. A general formulation of the normative geo-economic model in the spatially extended framework replaces equation (1):

$$
\max _{a(z, t)} \int_{0}^{T} \int_{0}^{Z} e^{-\delta t}(N B(q(z, t), a(z, t))) d z d t
$$

where $z \in[0, Z]$ indexes space. This formulation of the objective functional follows closely the theory in Brock \& Xepapadeas (2008), though specifying state equations with equivalent generality is problematic. If the process is diffusive, as in Gopalakrishnan et al. (2016) and implicitly in Brock \& Xepadadeas (2008), we can write:

$$
\frac{\partial q}{\partial t}=D \frac{\partial^{2} q}{\partial z^{2}}+G(q(z, t), a(z, t)) .
$$

where $D$ is the diffusion constant. The resulting optimization using a generalized Hamiltonian yields a system of partial differential equations (PDE) rather than ordinary differential equations (ODE), including a PDE co-state equation.

Brock \& Xepapadeas (2008) derive conditions for the emergence of spatial patterns that result from the diffusion of the resource stock and optimizing behavior of economic agents. A spatially heterogeneous steady state can result from the interaction between dynamics of the physical systems and human decisions. These spatial-dynamic problems can only be solved for special cases (notably problems that are linear-quadractic in form) and yield fewer intuitive insights than equivalent problems in renewable resource economics without the spatial-dynamic component (Smith, Sanchirico, \& Wilen 2009). Moreover, they are likely to be quite limited for understanding real coastlines because many processes in coastal geomorphology defy this simple description. For example, wave shadowing can produce emergent properties of coastlines that can only be modeled numerically (Ashton, Murray, \& Arnoult 2001). The implication is that developing both positive and normative insights about real-world coastlines will necessarily involve numerical modeling.

\section{Economic Values of Geomorphological Coastal Systems}

Functioning coastal ecosystems provide an array of economic benefits. Along passive geological margins, sandy sediments interact with waves, tides, currents, and biota to create barrier islands, salt marshes, estuaries, mud flats, and other habitat. The stock of sediments produces service flows within human societies that have co-evolved with the landforms associated with these systems. That is, different configurations of the coast could also be beneficial, but human 
societies have developed around particular manifestations, and maintaining those physical forms engender economic benefit.

Coastal beaches and dunes provide a protective buffer for buildings and infrastructure from strong waves and storm surge. Persistent waves and epidsodic storms deliver significant energy to the coastal environment, moving sediment, disturbing ecosystems, and damaging buildings and infrastructure. Robust dunes and beaches absorb a significant amount of this energy, protecting the hinterland. While much sediment moves offshore during storm conditions, most of the sand tends to return to the beach when conditions ameliorate. Alongshore sediment transport and sea level rise, in contrast, provide continuous press disturbances to the coastal zone, leading to long-term patterns of erosion and accretion. Coastal beaches and dunes provide space for recreation and leisure activities, while also supplying aesthetic values associated with the coastal landscape. Lastly, coastal sediments support healthy ecosystems, supplying ecological benefits associated with use and potentially non-use of the environment.

\section{Beach Recreation}

The NB function in equations (1) and (3) can reflect economic value of beach recreation. There are a number of studies that consider the effect of coastal erosion on beach recreation using stated preference, revealed preference, and combined methods. These studies find mixed statistical evidence regarding whether beach width is an important factor driving the number of beach trips and the value of those trips. In some studies that find statistically significant effects, the economic effects of beach width are small. In other studies, the welfare effects are reported on per trip basis or are based on a qualitative change in beach width (i.e. increase or decrease but not by specific amounts that allow for estimates of maginal value of width). Only one study reports values that allow an estimate of the value per foot, per mile of beach width. ${ }^{1}$

Parsons, Massey, \& Tomasi (1999) estimate the value of beach width at Delaware, Maryland, and New Jersey beaches using the travel cost method. They find that beach width between 75 and 200 feet is preferred in the site selection model. Avoiding a loss of beach width to below 75 feet is worth between $\$ 1$ and $\$ 9$ per trip. In a re-analysis of the data, Von Haefen, Massey, \& Adamowicz (2005) find similar results. Lew \& Larson $(2005,2008)$ estimate the value of a San Diego County beach day including erosion factors that affect sand quality, not beach width. The value of avoiding erosion of sand that exposes cobblestones is $\$ 6$ per trip. Whitehead et al. (2009) use the travel cost method to estimate the value of beach width for shore fishing. They find that beach width is a significant predictor of fishing site selection. The willingness to pay

\footnotetext{
${ }^{1}$ All of the dollar values are adjusted to 2015 dollars with the consumer price index.
} 
per trip is $\$ 10$ and $\$ 11$ is avoid reductions in beach width of 30 and 35 feet, respectively. Pendleton et al. (2012) estimate a travel cost model for Southern California beaches and find that beach visits increase with beach width nonlinearly and values differ across individual activity categories.

Several studies use the contingent valuation method. McConnell (1977) and Bell (1986) find that the economic value of beach recreation per person increases with increasing beach width due to the reduction in crowding associated with wider beaches. Silberman \& Klock (1988) estimate the recreation use values of beach nourishment in New Jersey. They find that visitation would increase substantially on the nourished beaches but decrease on other beaches. Lindsay et al. (1992) estimate willingness to pay for beach erosion protection measures, including seawalls and beach nourishment, in Maine and New Hampshire. Their focus is on factors that affect willingness to pay. Shivlani, Letson, \& Theis (2003) estimate the benefits of beach nourishment in south Florida. Willingness to pay for beach access increases with beach nourishment. Landry, Keeler, \& Kriesel (2003) estimate the value of various erosion management alternatives in Georgia. They find that beach goers who take day trips are willing to pay higher parking fees for beach nourishment. Rulleau \& Rey-Valette (2013) estimate the value of beach protection on the French Mediterranean. Logar \& van den Bergh (2014) estimate the value of avoiding beach erosion at Croatian beaches.

Several other studies use stated preference methods other than CVM. Huang, Poor, \& Zhao (2007) consider the tradeoffs associated with beach nourishment in New Hampshire and Maine using a choice experiment. One of the choice attributes is the preservation of a sandy beach that varies from one to four miles. They estimate that each beach mile saved is valued at about $\$ 4$ annually per respondent. Huang et al. (2011) use the same data combined with revealed preference trip frequency data. They find that the willingness to pay for an erosion control program that would avoid an annual 10 feet of beach erosion ranges from $\$ 22$ to $\$ 42$. Parsons et al. (2013) use revealed and stated preference trip frequency data to estimate the value of reducing width to $25 \%$ and for a doubling of width for Delaware Bay beaches. The willingness to pay avoid the loss of beach width is $\$ 5$ and $\$ 13$ per trip for day-trippers and overnighters, respectively. The willingness to pay to gain a doubling of width is $\$ 3$ and $\$ 7$ per trip for daytrippers and overnighters.

Several studies use data from a 2003 study of southern North Carolina beaches. Whitehead et al. (2008) combine revealed and stated preference trip demands for 17 beaches. One of the hypothetical scenarios is "adding an average of 100 feet to beach width with periodic beach nourishment every 3 to 5 years." The annual change in recreation value ranges from $\$ 79$ to $\$ 106$. The average beach length in this study is 4.63 miles. The average value per foot of beach width for each mile of beach is $\$ 0.17$ to $\$ 0.23$ per mile. Landry \& Liu (2009) use these data and 
estimate nonparametric revealed and stated preference models. They find that beach width increases recreation trips in only two of six econometric models. Landry \& Liu (2011) extend this analysis to several other parametric models and find that the beach width scenario increases recreation trips in three of four models.

Whitehead et al. (2010) examine beach recreation behavior using multiple-site, revealed preference data, exploiting the existing variation in beach width in the choice set of North Carolina beaches. The value of a 100-foot increase in beach width across all sites in the study area is estimated. This is compared to the value estimated from a model similar to Whitehead et al. (2008), but with a reduced sample size to facility comparison across similar samples, where aggregate-trip demand is estimated using revealed and stated preference data for a hypothetical 100 -foot increase in beach width. In both the multiple site revealed preference and revealed-and-stated preference single site models, respondents are estimated to take one extra trip per season as a result of the increased beach width. The range of annual willingness to pay for the 100 -foot increase in width is $\$ 136$ to $\$ 397$. The average value per foot of beach width is $\$ 0.29$ to $\$ 0.86$ for each mile of beach for this sub-sample of beach recreationists.

\section{Coastal Housing Markets}

Benefit flows in the coastal system are also capitalized in land and housing prices. A growing body of literature has employed the hedonic property price models (Rosen 1974) to infer economic values associated with the coastal environment. These studies find that proximity-towater and water-view have positive influences on housing sales prices (Leggett \& Bockstael 2000; Bin, Kruse, \& Landry 2008; Samarasinghe \& Sharp 2010; Bin et al. 2011), while flood and erosion risk associated with the coastal zone diminish housing values (Kriesel, Randall, \& Lichtkoppler 1993; Bin \& Polasky 2004; Bin, Kruse, \& Landry 2008; Samarasinghe \& Sharp 2010; Bin, et al. 2011; Rambaldi, et al. 2012; Jin et al. 2015). Further, evidence suggests that risk perceptions that drive price differentials can be influenced by the occurrence of natural disasters (Hallstrom \& Smith 2005; Carbone, Hallstrom, \& Smith 2006; Bin \& Landry 2013; Atreya, Ferreira, \& Kriesel 2013; Atreya \& Ferreira 2015).

More critical for the NB functions in equations (1) and (3) is the influence of coastal sediments on housing and land values. Hedonic price models have been used to estimate marginal implicit values of beach quality, typically measured as width (Pompe \& Rhinehart 1999; Parsons \& Powell 2001; Landry, Keeler, \& Kriesel 2003; Landry \& Hindsley 2011; Gopalakrishnan et al. 2011; Landry \& Allen 2016). Examples of empirical estimates of marginal willingness to pay for beach width ${ }^{1}$ are: $\$ 606 /$ foot for homes within 800 meters of the shoreline in Surfside Beach \& Garden City, South Carolina (evaluated at average beach width of 24 meters (Pompe and Rhinehart 1995)); \$601/ foot for homes within 300 meters of the shoreline in Tybee Island, 
Georgia (evaluated at average beach width of 26.5 meters (Landry and Hindsley 2011)); \$302/ foot for homes within 500 meters of the shoreline in Dare County, North Carolina (evaluated at average beach width of 49 meters (Landry and Allen 2016)); and \$155/ foot for all homes on Seabrook Island, South Carolina (evaluated at average beach width of 69 meters (Pompe and Rhinehart 1999)). This sampling of empirical results provides evidence of consistency in terms of overall and relative magnitudes (i.e. marginal value declining with additional width). Marginal WTP for beach width for beachfront homes are larger: \$1,332/ foot for homes in South Carolina (average beach width of 24 meters (Pompe and Rhinehart 1995)); and \$1,750/ foot for homes in North Carolina (average beach width of 29 meters (Gopalakrishnan, et al. 2011)). (See Landry (2011) for more details.)

Early research efforts in this area treated beach width as a spatially distinct characteristic with elements of a congestible public good (such as school quality or park space). Subsequent efforts have recognized the dynamic nature of beach quality (Landry \& Hindsley 2011; Gopalakrishnan et al. 2011; Landry \& Allen 2016); like other public goods and levels of externalities (Abelson \& Markandya 1985), beach sediments change with natural and anthropogenic forces. An advantage in studying beach sediments is that erosion rates and beach width have been tracked at fairly regular intervals for decades (though there is much variability in records depending upon the jurisdiction). Moreover, periodic beach nourishment results in measureable changes in beach quality, associated with detailed assessments of the beach environment.

In terms of hedonic price analysis, regressing current housing values on current levels of beach quality is a reasonable starting place, since current levels are observable (albeit perhaps with some subjective variability). Future levels of beach quality should also matter, but these attributes are uncertain, subject to natural variation, evolutionary trends, and policy intervention. Thus, interpretation of the marginal price estimates depends the perspectives of buyers and sellers and their expectations about future amenity flows (Landry \& Hindsley 2011; Gopalakrishnan et al. 2011). Landry \& Hindsley (2011) argue that, under these circumstances, conventional hedonic price parameter estimates may provide only bounds true marginal effects.

Utilization of beach replenishment as a risk mitigation and recreation enhancement strategy creates potential for reverse causation in hedonic property price models (Gopalakrishnan et al. 2011). Cost-benefit analysis is a typical requirement in policy analysis of potential replenishment projects, and protection of coastal property from hurricanes and erosion is a primary benefit criterion employed in analysis (Landry 2011). Thus, the value of coastal property can affect the decision of whether or not to replenish coastal beaches and the magnitude of project scope and resulting beach width. This could lead to reverse causation in 
regression models. Employing instrumental variables ${ }^{2}$ analysis to explore endogeneity, Gopalakrishnan et al. (2011) find evidence of significant downward bias in marginal implicit prices of beach width. Their estimates of marginal WTP for beach width increase roughly fourfold when using instrumental variables to control for endogeneity. This downward bias may also reflect errors-in-variables bias to the extent that current beach width is an imperfect proxy for future beach width.

Landry and Allen (2016) examine issues related to hedonic capitalization related to beach proximity and the potential for endogeneity along a North Carolina shoreline that has not undergone beach replenishment. They explore a number of specifications to capture the relationship between beach quality and proximity to the shore; their results suggest that dummy variables for discrete zones with particular shoreline proximity (each interacted with beach width) provide the best fit to the data. Using instrumental variables (distance to the "depth of closure" along the near-beach ocean bottom, distanc to the edge of the continental shelf, and wave energy in the nearshore environment), they too find some evidence of endogeneity, though significantly less support for endogeneity when spatial regression models are utilized. The mixed evidence of endogeneity is noteworthy. Since beaches in their dataset were not being replenished with beach sand, endogeneity must stem from errors-in-variables and not reverse causation. Variability in perceptions of beach width, expectations of future coastal change, and management interventions are likely candidates for sources of error in beach width variables.

Heterogeneity in the distribution of beach sediments and household-level variation in knowledge and expectations of coastal dynamics and management interventions could provide impetus for spatial sorting across the coastal landscape (Klaiber \& Phaneuf 2010; Kuminoff, Smith, \& Timmins 2013); this remains to be explored empirically. To better understand how coastal property markets respond to changes in the geophysical system and to policies that can affect the provision and distribution of beach amenities, we need empirical analyses that examine spatial heterogeneity to recover parameters informing the NB function in (1) and (3).

\section{Economic Costs of Shoreline Management}

Costs of shoreline management, which include both fixed and variable costs, depend on the type of management decision (e.g, nourishment, armor, or retreat) and geophysical characteristics of the shoreline. These costs enter the determination of the net benefits from shoreline management $N B$ in equations (1) and (3). The conventional policy of high fixed-cost investments in building hard structures, such as seawalls and jetties, to obstruct the waves and

\footnotetext{
2 Their instrumental variables are distance to the edge of the continental shelf (a bathometric measure) and presence of erosion scarps on the beach, each of which are arguably redundant in the hedonic price equation.
} 
reduce the velocity of ocean currents has fallen out of favor in the recent years, as this approach often exacerbates erosion in neighboring regions (Kraus \& Pilkey 1988; Pilkey \& Wright 1988) and even 10s of kilometers away (Ells \& Murray 2012). Beach nourishment also involves high fixed costs but, in contrast to hard structurs, includes substantial variables costs. Nourishment involves periodic investments in rebuilding a beach with sand dredged from another location, typically off shore or inlets (Dean 2002). The costs associated with implementing a nourishment project include construction costs, costs of periodic maintenance and any external costs, such as ecological impacts associated with a nourishment project. Rotational management decisions to determine optimal nourishment intervals (similar to the Faustmann model in forestry) can accommodate the periodic nature of investments that involve high fixed costs (Smith et al. 2009). Histocally, beach nourishment projects in the United States were primarily federally funded and implemented by the USACE, and cumulative federal appropriations for nourishment between 1954 and 2009 were estimated at \$2.9 billion (Coburn 2009). Currently, new beach nourishment projects are primarily being funded at the state and local levels, with the federal government providing oversight on permitting and environmental compliance. In either case, decisions about the design of particular nourishment projects are largely decentralized and made on a case-by-case basis for individual communities. Though the need for coordination is beginning to influence planning decisions, the lack of incentives to self organize presents policy challenges for systematic coordination across locations.

While there is a large body of non-market valuation studies that estimate the demand for shoreline management, economic costs of management are less studied. Estimates rely primarily on databases and records maintained by the USACE. Recent work develops an empirically-grounded dynamic model of optimal nourishment with strategic interaction between two communities (Gopalakrishnan et al. 2016). This paper uses available data from North Carolina to recover an estimate of annual variable nourishment costs per meter of additional beach width in order to parameterize the cost function in equation (1). As coastal communities continue to adapt to climate change, we can expect non-linear changes in the nourishment cost function. With growing demand for shoreline protection, nourishment sand reserves are depleting. Records maintained by Program for the Study of Developed Shorelines (PSDS) at Western Carolina University show that cost per cubic yard of nourishment sand has increased from less than 10 cents in 1950 to almost \$12 in 2010 (Gopalakrishnan, Landry \& Smith 2016). Numerical models of coastline change that incorporate increasing nourishment costs (reflecting depleting available sand reserves) show that optimal coastal response to sea level rise depends critically on the interactions between the distribution of property values and erosion rates along the coast (McNamara et al. 2011). The time path of nourishment sand costs and levels of property value determine the timing of abandoment of beach nourishment and the resulting cascade of effects on shoreline configuration (McNamara et al. 2011). 
There is significant heterogeneity in beach nourishment intervals and associated costs along the coast (Table 1). The average interval between nourishment operations in coastal North Carolina ranges from less than one-and-a-half years to almost six years. These differences are largely driven by variability in geophysical characteristics, but also by accessibility of suitable sand resources; appropriate distribution of sand grain size enhances stability and longevity of renourished beaches. Average cost per cubic yard also varies widely, from around $\$ 2.25$ to over $\$ 12.00$ ! In a simple analysis of trends in nourishment patterns for North Carolina, Gopalakrishnan, Landry \& Smith (2016) find that access to renewable sand deposits (i.e. from inlets and river channels) increases nourishment frequency relative to locations that rely on sand dredged from offshore deposits. These trends motivate the need for further empirical analysis to examine heterogeneity in the costs of shoreline management across locations in order to recover reliable estimates of cost parameters as a first step towards exploring spatialdynamic feedbacks in optimally managing coastlines specified in equation (3). In the next section we consider potential impacts of shoreline management decisions on the quality of ecosystem services.

\section{Ecological Services and Preferences for Shoreline Management}

To provide deeper insight into individual preferences for shoreline management options and their potential impact on economic value of ecological services, we analyze a stated preference dataset for North Carolina households (Landry and Whitehead 2015). North Carolina Sea Grant and East Carolina University sponsored data collection in 2014, and the project sought to elucidate economic values of shoreline management alternatives and how those values are affected by ecological impacts and resulting resource quality. Shoreline armoring has been proscribed in North Carolina since the 1980s, though some oceanfront properties facing high erosion risk use large sand bags to protect their homes. In 2011, the North Carolina legislature approved the use of terminal groins, ${ }^{3}$ and some suspect that they may permit more hardening of the shoreline in the near future. Beach nourishment is conducted along many parts of the North Carolina coast; some are a part of ongoing federal projects that were approved decades ago (e.g. Wrightsville Beach) and others funded locally (e.g. Carteret County). Like most parts of the U.S. coast, shoreline retreat is typically only employed as a measure of last resort, but there are parts of the North Carolina shore that have had to embrace retreat (e.g. South Nags Head).

The internet panel data were collected by Online Sampling Solutions, Inc., using the Research Now panel, ${ }^{4}$ which is designed for research purposes, actively managed, and recruited using standard marketing research techniques. We received a $61 \%$ response rate, and our data

\footnotetext{
${ }^{3}$ Groins are shore-perpendicular structures designed to protect downdrift land and/or trap sand. Terminal groins are found at the end of the beach, often adjacent to waterways.

${ }^{4}$ www.researchnow.com
} 
somewhat mirror the demographic characteristics of the population of North Carolina based on observable characterisitcs collected via U.S. Census (see Table 2).

The survey questionnaire included a short preamble to describe the resource problem under study and collected information on subjects' knowledge and beliefs about coastal processes and shoreline development. The survey is designed to assess a cooperative state/local program that would pursue a concerted strategy to manage erosion on all developed North Carolina beaches. The proffered strategies are beach replenishment, shoreline armoring in conjunction with beach replenishment, and shoreline retreat. Each of these was to be evaluated relative to the status quo-no state program. For each possible strategy, a brief description of the approach was provided.

In addition to information on recreation demand, the survey collected stated preference data to measure willingness to pay for beach erosion management. We utilized referendum contingent valuation questions about respondents' intentions to vote in support of the erosion management plan to which they were randomly assigned. The payment vehicle was described as an increase in overall state income tax accompanied by an increase in beach property taxes ( 2 cents per $\$ 100$ value). Since the data identifies beach homeowners, we are able to control both sources of payment in our analysis. The randomly assigned bid levels were $\$ 4, \$ 28, \$ 49$, $\$ 81$, and \$114 per household, per year, and the survey included text to enhance incentive compatibility (Landry and List 2007).

In order to evaluate resource quality and ecological impacts each respondent was assigned to one of four treatments: (1) wide beaches (50 foot average increase) and minimal environmental impacts, (2) wide beaches (50 foot average increase) with negative environmental impacts, (3) wider beaches (150 foot average increase) with minimal environmental impacts and (4) wider beaches (150 foot average increase) with negative environmental impacts. Descriptions of distinct negative environmental impacts of beach nourishment, armoring, and retreat were based on the balance of evidence in the ecological and management literature and were thoroughly described to respondents. In the "minimal environmental impacts" treatment, these effects were described as ameliorated through effective management.

Overall, $46 \%$ of the subjects indicated an affirmative response for their willingness-to-pay for the proffered erosion management program. We analyze the likelihood of affirmative votes in the referendum using a standard probit model. Results for treatment effects are presented in Table 3, and an expanded model with other covariates is presented in Table 4. The tax attribute is negative and statistically significant. The shoreline retreat scenario has a positive and statistically significant effect on support for shoreline erosion management (Table 4), while shoreline armoring is no different from beach replenishment (the excluded category). The presence of environmental impacts associated with erosion control reduces the likelihood of 
voting for the program but it does not vary with the type of management program. Voting responses are not sensitive to the resulting beach width (150 foot increase relative to 50 foot increase). Those that own a beach house are much more likely to support erosion management, but they have a lower preference for shoreline armoring relative to beach replenishment, whereas the point estimate of shoreline retreat is negative for this group, but not statistically significant. Those concerned about coastal erosion are more likely to support the project. The likelihood of an affirmative response is increasing in the number of children and household income. Lastly, all political ideologies appear to support the erosion management programs (in comparison to those who respond to political affilication as "none of the above"), with marginal effects for liberals and moderates exceeding the point estimate of conservatives.

The results indicate that coordinated coastal erosion management programs exhibit economic value for some North Carolina households. The mean willingness to pay is $\$ 37$ per household per year. ${ }^{5}$ This result is comparable to Huang et al. (2011), wherein they find WTP of \$22 to \$42 per year for erosion control. Shoreline retreat is the most preferred program with a mean willingness to pay of $\$ 61$ per household per year. As one might reasonably expect, those that own beach houses have the highest value for such programs with mean willingness to pay equal to \$193 per household per year; this subset of respondents has a lower preference for shoreline armoring reducing mean willingness to pay to $\$ 81$. While we find no additional benefit in increasing beach width by 150 feet relative to 50 feet, Parsons et al. (2013) find relatively small measures of WTP (\$3 and \$7 per trip) for increasing beach width from 50-100 to 100-200 feet. We present what we believe are some of the first estimates of economic costs stemming from erosion management impacts on ecological services of the shoreline. Negative environmental impacts associated with management of erosion decrease the economic value to a paltry $\$ 7$ per household per year, but our data cannot distinguish between the differences in these negative values amongst the various management regimes in this simple analysis. In summary, these survey responses capture important tradeoffs across the amenity values of wider beaches and the ecological costs of active engineering solutions to stabilize the shoreline.

\section{Adaptation}

As climate change accelerates the rate of coastline change, coastal planners are faced with questions of how to adapt. Trends in beach nourishment suggest that coastal communities are already adapting at the intensive margin (more frequent nourishments) and the extensive margin (more communities engaging in beach nourishment). In the long run, however, it is unclear whether beach nourishment will continue to be a sustainable management practice (Landry 2011; McNamara and Keeler 2013). In a single-community context, a dynamic optimization framework can evaluate long-run coastal adaptation decision, including the choice

\footnotetext{
${ }^{5}$ The welfare effects are estimated following Cameron and James (1987).
} 
of when to retreat, and allow communities to adjust more effectively to long-term risks (Landry 2011). Yohe et al (1995) analyze the retreat decision for an urban environment (Charleston, SC) in response to sea level rise. A similar approach can be used to analyze the transition away from beach nourishment along barrier islands (Landry 2011).

An important complication is the potential for spatial-dynamics (and not just spatial heterogeneity that might be captured as parameters) to influence the timing and nature of armoring or retreat. Numerical modeling in a spatially extended framework suggests that changes in the intensive margin (sand usage) will deplete available sand resources and force a movement away from beach nourishment (McNamara et al. 2011). Coastal communities draw from a common pool of sediment resources, with inlet dredge spoils being much more reliably dedicated to local communities than offshore sand resources. Excavation and transport costs can impose limitations on the ability to access offshore sand resources, and there is considerable uncertainty regarding the location and quality of sediments suitable for nourishment. Because property values influence the intensive margin, different communities will deplete their viable sand resources at different points in time. As communities stop stabilizing the shoreline at different times, spatial-dynamics create a cascade of effects that propagate over large distances (McNamara et al. 2011). Differences in management regimes across communities can also be affected by heterogeneous beliefs about geophysical conditions, including coastal erosion and storm return interval, as these factors can influence property purchase and sale decisions.

Agent-based modeling coupled with a spatially extended geophysical model shows that agents who place a higher weight on scientific projections of future coastline evolution invest heavily in defensive expenditures in the short term and then abandon the coastline as the system crosses a tipping point beyond which coastal real estate is not a viable economic investment (McNamara and Keeler 2013). These agent-based models of coastal evolution coupled with localized adaptaion policies augur a possible race to dredge sand reserves. Since nourishment quality sand is largely a common-pool resource, individual communities may accelerate their extraction of economically recoverable sand before other communities have a chance to access it. Observed trends in sand extracted and in the number of nourishment events could suggest a potential tragedy of the sand commons unfolding over the coming decades, an issue that requires further research.

Of course, communities are not simply facing a choice between beach nourishment and retreat from the shoreline. The use of shoreline armoring with hard structures is also in the mix. Depending on the preferences of individual communities and the physical forcing that they face, some sequencing of adaptation measures may be optimal. That is, as nourishment responds at the intensive margin, eventually it may no longer exhibit net benefits. Armoring the 
shoreline may then be optimal before a long-run retreat if communities are faced with inundation from sea level rise. Altering types of construction that are allowed (e.g. building houses on stilts) factors into adaptation as well. Thus, beach nourishment, retreat, hard structures, zoning, and building codes are all extensive margins of adaptation. Understanding these margins of adaptation and response is an essential next step to inform coastal climate adaptation policy.

\section{Discussion and Conclusions}

The models laid out in $(1-4)$ can provide a conceptual foundation for geo-economic modeling of the management of beach erosion and shoreline change. The framework has analyzed beach replenishment in models with a simplified spatial representation (Smith et al. 2009; Landry 2011; McNamara et al. 2015; Gopalakrishnan et al. 2016); expanding to more realistic spatial models will require numerical analysis. The conceptual framework should also be useful for analysis of the erection of shoreline protection structures and the implementation of a shoreline retreat policy. That is, the framework is relevant for exploring a wide range of coastal climate adaptation measures along the extensive margin.

To date, little is known about the optimal sequencing of extensive margin adaptations. Structural protection will engender near-term risk mitigation benefits for coastal property and infrastructure, while creating a diminution of the quality of the beach environment and negative ecological effects. Beach replenishment can be used to offset some of the negative effects, but it is likely to be more costly when used in conjunction with shoreline armoring. Shoreline retreat and adaptation can be modeled within the same conceptual framework; removing or relocating homes would diminish the magnitude of beneficiaries receiving service flows of coastal resources, but could increase the quality of coastal resources (which would ameliorate the net benefits). Adaptation plans that embrace managed or phased shoreline retreat should seek to optimize economic returns from timing and the spatial allocation of transitions.

Empirical estimates of the benefits stemming from changes in the shoreline environment have focused primarily on recreation and hedonic housing values. The coastal environment offers a rich array of recreational and leisure amenities, including ocean, estuary and marsh views; access to beaches and ocean waters; brackish and saltwater fishing; and historic and cultural resources. Recreation demand models have been widely employed to estimate the value of recreation and the influence of beach quality on recreation value. The literature is mixed on whether wider beaches add value to a recreation trip. Less is known about how recreation values respond to shoreline armoring or retreat. We provide some new evidence that suggests that negative environmental impacts of coastal erosion policies significantly reduce their value. 
The innate appeal of coastal location offers unique incentives for residential and commercial development; competitive market prices for differentiated coastal housing has permitted detailed analysis of the influence of beach quality and, to a lesser extent, shoreline armoring on property values. Issues that remain to be explored include how housing markets would respond to discrete changes in management, such as transition to a policy of shoreline retreat. Hedonic property models can utilize historic data on management changes (e.g. institution of setback policies based on historical erosion rates) to obtain a sense of how the market responds, but transferring these estimates to widespread retreat and adaptation would likely be problematic.

Existing data on the costs of shoreline management primarily relate to beach replenishment, and the information is somewhat incomplete regarding the resources utilized to maintain beaches and the technology employed. These limitations complicate use of production theory in modeling dynamic coastal management (e.g. estimation of a economic beach nourishment cost function).

Considering the conceptual and empirical gaps in our knowledge, producing integreated models for coastal climate adaptation rooted in sound economic empirical work is a daunting task. There are some clear paths forward for researchers, however. The modelling literature has pursued two parallel tracks with the goal of eventually achieving some synthesis (Murray et al. 2013). One track starts with a stylized single community and a single adaptation strategy and then begins to layer more geomorphological, spatial, and climate science realism (Smith et al. 2009; McNamara et al. 2015; Gopalakrishnan et al. 2016). A logical next step is to embed multiple adaptation strategies into this capital-theoretic framework and continue to build in more realism grounded in the physical science. The second track starts with sophisticated models of geomorphology and climate dynamics and embeds stylized economic decision rules into them (McNamara et al. 2011), with recent attempts to include some capital-theoretic underpinnings (Lazaurs et al. 2011; Williams et al. 2013). These numerical frameworks deal more seamlessly with spatial-dynamics and multiple adaptation strategies at the extensive margin but are not constructed to be optimized. So for this track, important next steps will be to include more economic (as well as political and psychological) realism into the decision rules and to develop frameworks for evaluating second-best solutions (if not fully optimized policy rules). Mostly separate from the modelling literature, the valuation literature is producing empirical content for more elaborate and comprehensive parameterizations of the net benefits function in these models. It is critical that the valuation literature continues to advance in ways that produce meaningful outputs for integrated models, while more work on the costs side of coastal interventions is also essential. 


\section{References:}

Abelson, P.W. and Markandya, A., 1985. The interpretation of capitalized hedonic prices in a dynamic environment. Journal of Environmental Economics and Management, 12(3), pp.195-206.

Ashton, A., Murray, A.B. and Arnoult, O., 2001. Formation of coastline features by large-scale instabilities induced by high-angle waves. Nature,414(6861), pp.296-300.

Atreya, A., Ferreira, S. and Kriesel, W., 2013. Forgetting the flood? An analysis of the flood risk discount over time. Land Economics, 89(4), pp.577-596.

Atreya, A., Ferreira, S. and Michel-Kerjan, E., 2015. What drives households to buy flood insurance? New evidence from Georgia. Ecological Economics,117, pp.153-161.

Bell, F.W., 1986. Economic policy issues associated with beach renourishment. Review of Policy Research, 6(2), pp.374-381.

Bennear, L.S. and Stavins, R.N., 2007. Second-best theory and the use of multiple policy instruments. Environmental and Resource Economics, 37(1), pp.111-129.

Bin, O. and Landry, C.E., 2013. Changes in implicit flood risk premiums: Empirical evidence from the housing market. Journal of Environmental Economics and management, 65(3), pp.361-376.

Bin, O. and Polasky, S., 2004. Effects of flood hazards on property values: evidence before and after Hurricane Floyd. Land Economics, 80(4), pp.490-500.

Bin, O., Crawford, T.W., Kruse, J.B. and Landry, C.E., 2008. Viewscapes and flood hazard: Coastal housing market response to amenities and risk. Land Economics, 84(3), pp.434-448.

Bin, O., Kruse, J.B. and Landry, C.E., 2008. Flood hazards, insurance rates, and amenities: Evidence from the coastal housing market. Journal of Risk and Insurance, 75(1), pp.63-82.

Brock, W. and Xepapadeas, A., 2008. Diffusion-induced instability and pattern formation in infinite horizon recursive optimal control. Journal of Economic Dynamics and Control, 32(9), pp.2745-2787.

Brock, W. and Xepapadeas, A., 2010. Pattern formation, spatial externalities and regulation in coupled economic-ecological systems. Journal of Environmental Economics and Management, 59(2), pp.149-164.

Cameron, T. A. and James, M.D. 1987. Efficient estimation methods for "closed ended" contingent valuation surveys. The Review of Economics and Statistics, 62(9), pp. 269-276.

Carbone, J.C., Hallstrom, D.G. and Smith, V.K., 2006. Can natural experiments measure behavioral responses to environmental risks? Environmental and Resource Economics, 33(3), pp.273-297.

Clark, C.W. and Munro, G.R., 1975. The economics of fishing and modern capital theory: a simplified approach. Journal of environmental economics and management, 2(2), pp.92-106.

Coburn, T. 2009. Washed Out to Sea: How Congress Prioritizes Beach Pork Over National Needs. United States Senate, 111th Congress, Congressional Oversight \& Investigation Report.

Dean, R. G. 2002. Beach nourishment: theory and practice. World Scientific, River Edge, NJ.

Ells, K. and Murray, A.B., 2012. Long-term, non-local coastline responses to local shoreline stabilization. Geophysical Research Letters, 39(19).

Gopalakrishnan S., Landry, C.L., and Smith, M.D. 2016. Coastal Climate Adaptation: A Grand Challenge for Environmental and Resource Economics. In Review. 
Gopalakrishnan, S., McNamara, D., Smith, M.D. and A.B. Murray. 2016. Decentralized Management Hinders Coastal Climate Adaptation: The Spatial-Dynamics of Beach Nourishment. Working Paper Available at SSRN: http://ssrn.com/abstract=2457631.

Gopalakrishnan, S., Smith, M.D., Slott, J.M. and Murray, A.B., 2011. The value of disappearing beaches: a hedonic pricing model with endogenous beach width. Journal of Environmental Economics and Management, 61(3), pp.297-310.

Gordon, H. S. 1954. The Economic Theory of a Common-Property Resource: The Fishery. Journal of Political Economy 62, 124-142.

Green, C. and Penning-Rowsell, E., 1999. Inherent conflicts at the coast. Journal of Coastal Conservation, 5(2), pp.153-162.

Hallstrom, D.G. and Smith, V.K., 2005. Market responses to hurricanes. Journal of Environmental Economics and Management, 50(3), pp.541-561.

Hartman, R., 1976. The harvesting decision when a standing forest has value. Economic inquiry, 14(1), pp.52-58.

Homans, F.R. and Wilen, J.E., 1997. A model of regulated open access resource use. Journal of Environmental Economics and Management, 32(1), pp.1-21.

Hotelling, H., 1931. The economics of exhaustible resources. The journal of political economy, pp.137175.

Huang, J., Parsons, G.R., Poor, P.J. and Zhao, M.Q., 2011. 9 Combined conjoint-travel cost demand model for measuring the impact of erosion and erosion control programs on beach recreation. Preference Data for Environmental Valuation: Combining Revealed and Stated Approaches.

Huang, J.C., Poor, P.J. and Zhao, M.Q., 2007. Economic valuation of beach erosion control. Marine Resource Economics, pp.221-238.

Jin, D., Ashton, A.D. and Hoagland, P., 2013. Optimal responses to shoreline changes: an integrated economic and geological model with application to curved coasts. Natural Resource Modeling, 26(4), pp.572-604.

Klaiber, H.A. and Phaneuf, D.J., 2010. Valuing open space in a residential sorting model of the Twin Cities. Journal of Environmental Economics and Management, 60(2), pp.57-77.

Kraus, N.C. and Pilkey, O.H., 1988. The Effects of Seawalls on the Beach. Special Issue. Journal of Coastal Research, SI, 4.

Kriesel, W., Randall, A. and Lichtkoppler, F., 1993. Estimating the benefits of shore erosion protection in Ohio's Lake Erie housing market. Water Resources Research, 29(4), pp.795-801.

Kuminoff, N.V., Smith, V.K. and Timmins, C., 2013. The new economics of equilibrium sorting and policy evaluation using housing markets. Journal of Economic Literature, 51(4), pp.1007-1062.

Landry, C.E., 2011. Coastal erosion as a natural resource management problem: an economic perspective. Coastal Management, 39(3), pp.259-281.

Landry, C.E., and Allen, T. 2016. Hedonic Property Prices and Coastal Beach Width. University of Georgia. Working Paper Series Available at SSRN 2474276. 
Landry, C.E. and Hindsley, P., 2011. Valuing beach quality with hedonic property models. Land Economics, 87(1), pp.92-108.

Landry, C.E., Keeler, A.G. and Kriesel, W., 2003. An economic evaluation of beach erosion management alternatives. Marine Resource Economics, pp.105-127.

Landry, C.E. and List, J.A., 2007. Using ex ante approaches to obtain credible signals for value in contingent markets: evidence from the field. American Journal of Agricultural Economics, 89(2), pp.420-429.

Landry, C.E. and Liu, H., 2009. A semi-parametric estimator for revealed and stated preference data-An application to recreational beach visitation. Journal of Environmental Economics and Management, 57(2), pp.205-218.

Landry, C.E. and Liu, H., 2011. Econometric models for joint estimation of revealed and stated preference site-frequency recreation demand models. Preference data for environmental valuation: Combining revealed and stated approaches, pp.87-100.

Landry, Craig E., and John C. Whitehead, 2015. Economic values of voastal vrosion management: joint estimation of use and passive use values with recreation and contingent valuation data. Selected Paper prepared for presentation for the 2015 Agricultural \& Applied Economics Association and Western Agricultural Economics Association Annual Meeting, San Francisco, CA, July 26-28.

Lazarus, E.D., McNamara, D.E., Smith, M.D., Gopalakrishnan, S. and Murray, A.B., 2011. Emergent behavior in a coupled economic and coastline model for beach nourishment. Nonlinear Processes in Geophysics, 18(6), pp.989-999.

Leggett, C.G. and Bockstael, N.E., 2000. Evidence of the effects of water quality on residential land prices. Journal of Environmental Economics and Management, 39(2), pp.121-144.

Lew, D.K. and Larson, D.M., 2005. Valuing recreation and amenities at San Diego County beaches. Coastal Management, 33(1), pp.71-86.

Lew, D.K. and Larson, D.M., 2008. Valuing a beach day with a repeated nested logit model of participation, site choice, and stochastic time value. Marine Resource Economics, pp.233-252.

Lindsay, B.E., Halstead, J.M., Tupper, H.C. and Vaske, J.J., 1992. Factors influencing the willingness to pay for coastal beach protection. Coastal Management, 20(3), pp.291-302.

Logar, I. and van den Bergh, J.C., 2014. Economic valuation of preventing beach erosion: comparing existing and non-existing beach markets with stated and revealed preferences. Journal of Environmental Economics and Policy, 3(1), pp.46-66.

McConnell, K.E., 1977. Congestion and willingness to pay: a study of beach use. Land economics, pp.185195.

McNamara, D.E. and Keeler, A., 2013. A coupled physical and economic model of the response of coastal real estate to climate risk. Nature Climate Change, 3(6), pp.559-562.

McNamara, D.E., Gopalakrishnan, S., Smith, M.D. and Murray, A.B., 2015. Climate Adaptation and PolicyInduced Inflation of Coastal Property Value. PloS one, 10(3), p.e0121278.

McNamara, D.E., Murray, A.B. and Smith, M.D., 2011. Coastal sustainability depends on how economic and coastline responses to climate change affect each other. Geophysical Research Letters, 38(7).

Murray, A.B., Gopalakrishnan, S., McNamara, D.E. and Smith, M.D., 2013. Progress in coupling models of human and coastal landscape change.Computers \& Geosciences, 53, pp.30-38. 
Nordhaus, W.D., 2006. The economics of hurricanes in the United States (No. w12813). National Bureau of Economic Research.

Parsons, G.R., Chen, Z., Hidrue, M.K., Standing, N. and Lilley, J., 2013. Valuing Beach Width for Recreational Use: Combining Revealed and Stated Preference Data. Marine Resource Economics, 28(3), pp.221-241.

Parsons, G.R., Massey, D.M. and Tomasi, T., 1999. Familiar and favorite sites in a random utility model of beach recreation. Marine Resource Economics, pp.299-315.

Parsons, George R., and Michael Powell. 2001. Measuring the cost of beach retreat. Coastal Management 29 (2): 91-103.

Pendleton, L., King, P., Mohn, C., Webster, D.G., Vaughn, R. and Adams, P.N., 2011. Estimating the potential economic impacts of climate change on Southern California beaches. Climatic Change, 109(1), pp.277-298.

Pendleton, L., Mohn, C., Vaughn, R.K., King, P. and Zoulas, J.G., 2012. Size matters: the economic value of beach erosion and nourishment in Southern California. Contemporary Economic Policy, 30(2), pp.223-237.

Pilkey, O.H. and Wright III, H.L., 1988. Seawalls versus beaches. Journal of Coastal Research, pp.41-64.

Pompe, Jeffrey J., and James R Rinehart.1999. Establishing Fees for Beach Protection: Paying for a Public Good. Coastal Management, 27, 57-67.

Rambaldi, A.N., Fletcher, C.S., Collins, K. and McAllister, R.R., 2012. Housing shadow prices in an inundation-prone suburb. Urban Studies, p.0042098012465904.

Rosen, S., 1974. Hedonic prices and implicit markets: product differentiation in pure competition. The journal of political economy, pp.34-55.

Rulleau, B. and Rey-Valette, H., 2013. Valuing the benefits of beach protection measures in the face of climate change: a French case-study.Journal of Environmental Economics and Policy, 2(2), pp.133147.

Samarasinghe, O. and Sharp, B., 2010. Flood prone risk and amenity values: a spatial hedonic analysis. Australian Journal of Agricultural and Resource Economics, 54(4), pp.457-475.

Samuelson, P.A., 1976. Economics of forestry in an evolving society. Economic inquiry, 14(4), pp.466492.

Scott, A. 1955. Natural resources : the economics of conservation. Toronto: University of Toronto Press.

Shivlani, M.P., Letson, D. and Theis, M., 2003. Visitor preferences for public beach amenities and beach restoration in South Florida. Coastal Management, 31(4), pp.367-385.

Silberman, J. and Klock, M., 1988. The recreation benefits of beach renourishment. Ocean and Shoreline Management, 11(1), pp.73-90.

Silberman, J., Gerlowski, D.A. and Williams, N.A., 1992. Estimating existence value for users and nonusers of New Jersey beaches. Land Economics, pp.225-236.

Slott, J.M., Murray, A.B. and Ashton, A.D., 2010. Large-scale responses of complex-shaped coastlines to local shoreline stabilization and climate change. Journal of Geophysical Research: Earth Surface (2003-2012),115(F3). 
Smith, M.D., A.B. Murray, S. Gopalakrishnan, A.G. Keeler, C.E. Landry, D. McNamara, L. Moore. 2015. 'Geoengineernig Coastlines? From accidental to intentional' in Baztan, J., O. Chouinard, B. Jorgensen, P. Tett, J. -P. Vanderlinden, and L. Vasseur (eds), Coastal Zones: Solutions for the 21st Century. Elsevier.

Smith, M.D., Sanchirico, J.N. and Wilen, J.E., 2009. The economics of spatial-dynamic processes: applications to renewable resources. Journal of Environmental Economics and Management, 57(1), pp.104-121.

Smith, M.D., Slott, J.M., McNamara, D. and Murray, A.B., 2009. Beach nourishment as a dynamic capital accumulation problem. Journal of Environmental Economics and Management, 58(1), pp.58-71.

Smith, V.L., 1969. On models of commercial fishing. The Journal of Political Economy, pp.181-198.

United States Army Corps of Engineers (USACE). 2000. Planning Guidance Notebook, ER 1105-2-100, Department of the Army: Washington, DC.

Von Haefen, R.H., Massey, D.M. and Adamowicz, W.L., 2005. Serial nonparticipation in repeated discrete choice models. American Journal of Agricultural Economics, 87(4), pp.1061-1076.

Whitehead, J.C., Dumas, C.F., Herstine, J., Hill, J. and Buerger, B., 2008. Valuing beach access and width with revealed and stated preference data.Marine Resource Economics, pp.119-135.

Whitehead, J.C., Phaneuf, D.J., Dumas, C.F., Herstine, J., Hill, J. and Buerger, B., 2010. Convergent validity of revealed and stated recreation behavior with quality change: a comparison of multiple and single site demands. Environmental and Resource Economics, 45(1), pp.91-112.

Whitehead, J.C., Poulter, B., Dumas, C.F. and Bin, O., 2009. Measuring the economic effects of sea level rise on shore fishing. Mitigation and adaptation strategies for global change, 14(8), pp.777-792.

Williams, Z.C., McNamara, D.E., Smith, M.D., Murray, A.B. and Gopalakrishnan, S., 2013. Coupled economic-coastline modeling with suckers and free riders. Journal of Geophysical Research: Earth Surface,118(2), pp.887-899.

Yoe, C. 1993. National Economic Development Procedures Manual: National Economic Development

Costs, DACWC72-90-D-0002, U.S. Army Corps of Engineers, Institute for Water Resources: Fort Belvoir, VA.

Yohe, G., Neumann, J. and Ameden, H., 1995. Assessing the economic cost of greenhouse-induced sea level rise: methods and application in support of a national survey. Journal of Environmental Economics and Management,29(3), pp.S78-S97. 


\section{(a) Alongshore dynamics of beach nourishment}

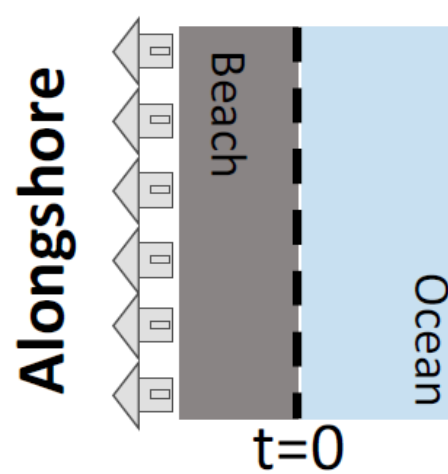

Pre-nourishment

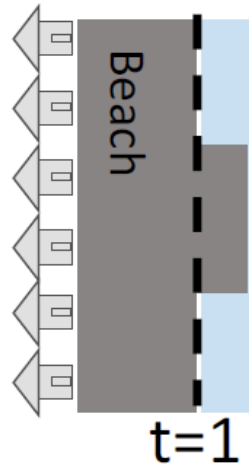

Nourishment

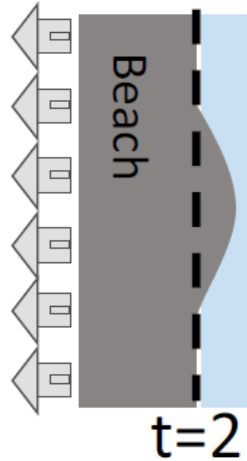

Post-nourishment

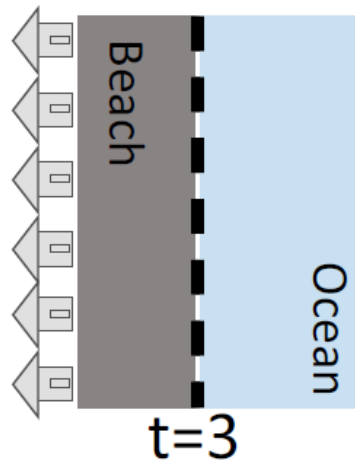

Re-equilibrated shoreline

(b) Cross-shore dynamics of beach nourishment

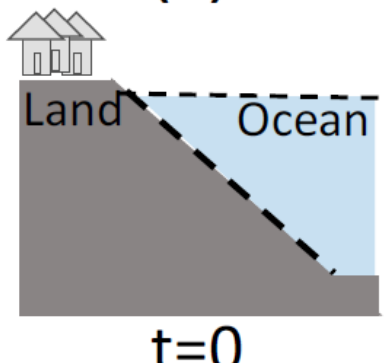

$t=0$

Pre-nourishment

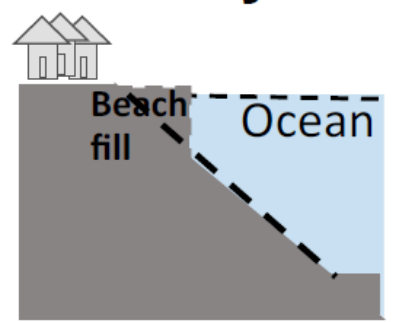

$$
t=1
$$

Nourishment

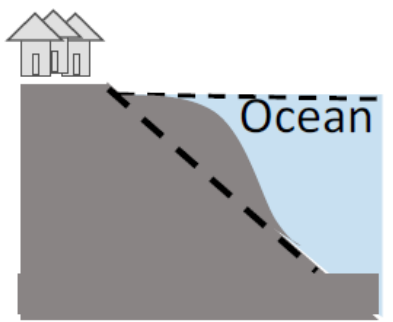

$t=2$

Post-Nourishment

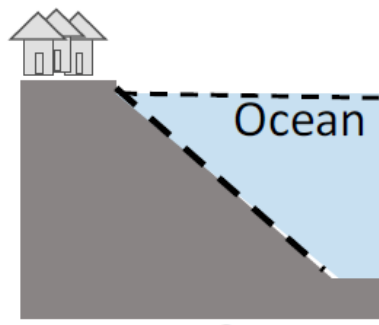

$t=3$

Re-equilibrated shoreface

\section{Cross-shore}

Figure 1. Beach nourishment accelerates erosion due to diffusive dynamics in the (a) alongshore dimension and (b) cross-shore dimension. 
Table 1: Distribution of Nourishment Costs—North Carolina

\begin{tabular}{lrrrr}
\hline & $\begin{array}{r}\text { Average Costs } \\
(\mathbf{1 0 0 0} \$ \mathbf{)}\end{array}$ & $\begin{array}{r}\text { Average } \\
\text { Cost/ Yd }\end{array}$ & $\begin{array}{r}\text { Nourish } \\
\text { Interval } \\
\text { Beach Location }\end{array}$ & $\begin{array}{r}\text { \# Nourish } \\
\text { Events }\end{array}$ \\
\hline Atlantic Beach/Fort Macon & $\$ 3,848.34$ & $\$ 6.65$ & 5.89 & 10 \\
Bald Head Island & $\$ 4,009.82$ & $\$ 4.58$ & 2.00 & 11 \\
Carolina Beach & $\$ 2,490.32$ & $\$ 2.29$ & 2.04 & 27 \\
Emerald Isle & $\$ 10,750.00$ & $\$ 10.13$ & 1.93 & 15 \\
Figure Eight Island & $\$ 1,624.07$ & $\$ 5.50$ & 2.56 & 10 \\
Holden Beach & $\$ 225.73$ & $\$ 4.49$ & 1.30 & 28 \\
Indian Beach/Salter Path & $\$ 6,394.80$ & $\$ 9.14$ & 2.00 & 2 \\
Kure Beach & $\$ 6,935.97$ & $\$ 6.49$ & 2.67 & 7 \\
Masonboro Island & $\$ 1,516.43$ & $\$ 5.41$ & 5.00 & 5 \\
Nags Head & $\$ 36,000.00$ & $\$ 7.83$ & & 1 \\
Oak Island & $\$ 3,371.55$ & $\$ 4.67$ & 5.75 & 5 \\
Ocean Isle Beach & $\$ 5,791.06$ & $\$ 5.85$ & 3.64 & 12 \\
Pine Knoll Shores & $\$ 12,836.19$ & $\$ 12.13$ & 4.00 & 3 \\
Topsail Island & $\$ 285.10$ & $\$ 3.86$ & 4.00 & 6 \\
West Onslow Beach & $\$ 417.98$ & $\$ 4.11$ & & 1 \\
Wrightsville Beach & $\$ 2,400.75$ & $\$ 2.83$ & 2.39 & 18 \\
\hline
\end{tabular}


Table 2: Descriptive Statistics for North Carolina Sea Grant Data

\begin{tabular}{lrrr}
\hline Variable & Mean & Std Dev & U.S. cencus (NC) \\
\hline Male & 0.467 & $(0.0194)$ & 0.487 \\
Household size & 2.319 & $(0.0424)$ & 2.5 \\
Children & 0.356 & $(0.0328)$ & - \\
White & 0.897 & $(0.0118)$ & 0.719 \\
High school & 0.0574 & $(0.009)$ & \\
College & 0.364 & $(0.0185)$ & 0.265 (Bachelors +) \\
Graduate school & 0.343 & $(0.0185)$ & \\
Env. Membership & 0.0846 & $(0.0108)$ & \\
Beach house owner & 0.0529 & $(0.0087)$ & \\
Income (1000s \$) & 93.29 & $(2.1724)$ & 46.291 (Median) \\
Liberal & 0.189 & $(0.0152)$ & \\
Moderate & 0.399 & $(0.019)$ & \\
Conservative & 0.347 & $(0.0185)$ & \\
Voter in 2012 & 0.882 & $(0.0125)$ & \\
\hline Number of Obs. & 662 & & \\
\hline
\end{tabular}


Table 3: Probit Model for Treatment Effects

\begin{tabular}{llr}
\hline Vote $=1$ & Coeff. & Std. Error \\
\hline Tax & $-0.0058^{* * *}$ & $(0.0011)$ \\
Armor & -0.1138 & $(0.2134)$ \\
Retreat & -0.0892 & $(0.2101)$ \\
Environmental Impact & $-0.4840^{* * *}$ & $(0.1727)$ \\
Armor x Env. Impact & -0.3435 & $(0.2462)$ \\
Retreat x Env. Impact & 0.2443 & $(0.2405)$ \\
Beach_150ft & -0.2071 & $(0.1726)$ \\
Armor x (Beach_150ft) & 0.0147 & $(0.2458)$ \\
Retreat x (Beach_150ft) & 0.3284 & $(0.2401)$ \\
Constant & $0.5113^{* * *}$ & $(0.1689)$ \\
\hline Observations & 704 & \\
\hline Standard errors in parentheses & \\
$*$ p $<0.10, * * p<0.05, * * * p<0.01$ & \\
\hline
\end{tabular}


Table 4: Probit Model with Treatment Effects and Household Characteristics

\begin{tabular}{|c|c|c|}
\hline Vote $=1$ & Coeff. & Std. Error \\
\hline $\operatorname{Tax}$ & $-0.0093^{* * *}$ & $(0.0015)$ \\
\hline Armor & -0.1788 & $(0.1397)$ \\
\hline Retreat & $0.3244^{* *}$ & $(0.1392)$ \\
\hline Beach House & $1.5392 * * *$ & $(0.4084)$ \\
\hline Armor x Beach House & $-1.0343^{*}$ & $(0.5409)$ \\
\hline Retreat x Beach House & -0.7556 & $(0.5998)$ \\
\hline Environmental impact & $-0.5645^{* * *}$ & $(0.1101)$ \\
\hline Beach_150ft & -0.0305 & $(0.1103)$ \\
\hline SLR & 0.2096 & $(0.1403)$ \\
\hline Hurricane & 0.1033 & $(0.1219)$ \\
\hline Erosion & $0.5668^{* * *}$ & $(0.1644)$ \\
\hline Children & $0.1561^{* *}$ & $(0.0644)$ \\
\hline Education & 0.1030 & (0.1309) \\
\hline Env. Membership & -0.0681 & $(0.1980)$ \\
\hline Income & $0.0018 *$ & $(0.0010)$ \\
\hline Liberal & $0.6243^{* *}$ & $(0.2815)$ \\
\hline Moderate & $0.6054^{* *}$ & $(0.2599)$ \\
\hline Conservative & $0.4596 *$ & $(0.2618)$ \\
\hline Constant & $-0.9359 * * *$ & $(0.3111)$ \\
\hline Observations & 621 & \\
\hline \multicolumn{3}{|c|}{$\begin{array}{l}\text { Standard errors in parentheses } \\
p<0.10, * * p<0.05, * * * p<0.01\end{array}$} \\
\hline \multicolumn{3}{|c|}{$\begin{array}{l}\text { SLR, Hurricane, and Erosion are dummy variables } \\
\text { indicating agreement with statements regarding } \\
\text { environmental problems stemming from those sources }\end{array}$} \\
\hline
\end{tabular}

